\title{
“AS MÃOS E OS PÉS DO CHARQUEADOR": O PROCESSO DE FABRICAÇÃO DO CHARQUE E UM PERFIL DOS TRABALHADORES ESCRAVOS NAS CHARQUEADAS DE PELOTAS, RIO GRANDE DO SUL $(\mathbf{1 8 3 0}-1885)^{1}$
}

Jonas Moreira Vargas ${ }^{2}$

Bastante estimado entre as populações pobres das grandes cidades litorâneas, o charque (carne-seca) era principalmente consumido pelos trabalhadores cativos das plantations do Sudeste e do Nordeste do Brasil. Segundo João Fragoso, estas se apresentavam como o principal centro de demanda de alimentos do Império. Por volta de 1830, por exemplo, cerca de $1 / 4$ das despesas das grandes plantações cafeicultoras do vale do Paraíba do Sul se constituía em gêneros para os escravos. No século XVIII, nas plantações beneditinas da Bahia, tal índice chegou a $30 \%$ dos gastos efetuados pelas mesmas ${ }^{3}$. No Rio Grande do Sul, as primeiras charqueadas instaladas nos fins do século XVIII surgiram da necessidade de suprir esta crescente demanda. $\mathrm{Na}$ realidade, elas foram fruto de investimentos de comerciantes que viram uma oportunidade de preencher um espaço aberto com a crise da produção de carne salgada no nordeste do Brasil, ocasionada pelas duras secas que afetaram aquela região ${ }^{4}$. Ao longo de todo o século XIX, o charque e os couros foram os principais produtos exportados pelo Rio Grande do Sul. Somados ao sebo, à graxa e aos chifres - bens também produzidos nas charqueadas - eles chegaram a atingir $85 \%$ das negociações no período ${ }^{5}$.

Sem o acesso ao tráfico transatlântico, a montagem do complexo charqueador pelotense teria sido inviável. Cada estabelecimento exigia um grande número de mão de obra nas distintas etapas de produção e a análise dos inventários post-mortem que realizo ao longo do artigo revela uma média entre 55 e 65 escravos por proprietário. Com a instalação das charqueadas, Pelotas tornou-se uma cidade negra. Em 1833, por exemplo, somente $1 / 3$ de sua população havia sido classificada como branca, sendo mais da metade dela formada por escravos. Nos anos 1870, quando Pelotas possuía mais de 25 mil habitantes, cerca de $1 / 3$ era formada por escravos. Boa parte deles estava concentrada nas fábricas de charque. Se em 1822, havia 22 charqueadas na localidade, em 1850, este número atingiu a casa dos 30 , em 1873, chegou aos 35

\footnotetext{
${ }^{1}$ A pesquisa que originou este artigo foi financiada por uma Bolsa de Doutorado do CNPq.

2 Doutor em História Social pela Universidade Federal do Rio de Janeiro. Professor Adjunto do Departamento e do Programa de Pós-Graduação em História da Universidade Federal de Pelotas. EMail: <jonasmvargas@yahoo.com.br>.

${ }^{3}$ FRAGOSO, João L. R. Homens de Grossa Aventura: acumulação e hierarquia na praça mercantil do Rio de Janeiro (1790-1830). Rio de Janeiro: Civilização Brasileira, 1998, p. 180.

${ }^{4}$ OSÓRIO, Helen. O império português no sul da fronteira: estancieiros, lavradores e comerciantes. Porto Alegre: UFRGS, 2007.

${ }^{5}$ VARGAS, Jonas Moreira. Pelas margens do Atlântico: um estudo sobre elites locais e regionais no Brasil a partir das famílias proprietárias de charqueadas em Pelotas, Rio Grande do Sul (século XIX). Tese (Doutorado em História Social). Universidade Federal do Rio de Janeiro. Rio de Janeiro, 2013.
} 
e em 1880, 38. As 11 charqueadas de 1900 indicam que o declínio do setor coincidiu com a abolição da escravidão (1888) e a queda da própria monarquia (1889). A escravidão não apenas viabilizou o surgimento da própria cidade como enriqueceu os proprietários das fábricas de charque, tornando-os os proprietários mais ricos do Rio Grande do Sul ${ }^{6}$.

Neste sentido, parafraseando o comentário que o jesuíta André João Antonil fez com relação aos engenhos de açúcar nos séculos XVII e XVIII, pode-se dizer que os escravos eram as mãos $e$ os pés do charqueador. Contudo, estes escravos não estavam igualmente distribuídos. O presente artigo trata do perfil da mão de obra escrava no complexo charqueador pelotense e de como os cativos estavam divididos nas unidades produtivas dos charqueadores. Apesar do tema já ter sido tratado parcialmente por outros autores, ofereço uma análise mais complexa, a partir de outros critérios metodológicos e da proposição de questões ainda não tratadas com relação a este tema ${ }^{7}$. No entanto, para compreender melhor estas questões é necessário verificar as etapas de produção do charque, pois tal fenômeno, com toda a sua complexidade, acabava por afetar a diferenciação não apenas da posição dos cativos no interior do plantel, como as próprias possibilidades de enriquecimento dos senhores.

\section{As Etapas do Processo Produtivo}

Antes de analisar a forma como os escravos estavam inseridos no mundo do trabalho das charqueadas é necessário descrever o processo de produção do charque $e$ dos couros desde a chegada dos animais vacuns nos estabelecimentos até o encaminhamento final dos produtos beneficiados. Todas as charqueadas ficavam dispostas nas margens fluviais do município, sendo que quase $90 \%$ delas nas do São Gonçalo e do Pelotas. A análise dos inventários post-mortem dos charqueadores demonstra que uma charqueada podia ser composta por diversas benfeitorias $e$ possuir inúmeros equipamentos e utensílios no seu espaço de trabalho, variando de acordo com a riqueza do seu proprietário. Nas primeiras décadas do século XIX era comum que os encarregados em arrolar os bens separassem as instalações no momento da avaliação, destacando a barraca de couros, o galpão de charquear, a graxeira, a mangueira, a senzala, o forno de secar sal, os varais, as caldeiras, entre outros. Com o tempo, e, sobretudo na segunda metade do oitocentos, essas mesmas

\footnotetext{
${ }^{6}$ VARGAS, Pelas margens do Atlântico..., 2013.

${ }^{7}$ CORSETTI, Berenice. Estudo da charqueada escravista gaúcha no século XIX. Dissertação (Mestrado em História). Universidade Federal Fluminense. Niterói, 1983. GUTIERREZ, Ester J. B. Negros, charqueadas \& olarias: um estudo sobre o espaço pelotense. Pelotas: UFPel, 2001. ASSUMPÇÃO, Jorge Euzébio. Pelotas: escravidão e charqueadas (1780-1888). Dissertação (Mestrado em História). Pontifícia Universidade do Rio Grande do Sul. Porto Alegre, 1995. MAESTRI, Mário. O escravo no Rio Grande do Sul: a charqueada e a gênese do escravismo gaúcho. Porto Alegre: EST, 1984. Mais recentemente, alguns trabalhos renovaram os seus olhares para este mesmo objeto. Ver, por exemplo: PESSI, Bruno. O impacto do fim do tráfico na escravaria das charqueadas pelotenses (c. 1846 - c. 1874). Monografia (Graduação em História). Universidade Federal do Rio Grande do Sul. Porto Alegre, 2008. PINTO, Natália Garcia. A benção compadre: experiências de parentesco, escravidão e liberdade em Pelotas (1830-1850). Dissertação de (Mestrado em História). Universidade do Vale do Rio dos Sinos. São Leopoldo, 2012.
} 
instalações passaram a ser avaliadas unicamente sob a denominação de "um estabelecimento de charqueada" ou "uma charqueada", sem discriminar todas as suas benfeitorias. A organização das mesmas, assim como as técnicas de preparo do produto e dos subprodutos, como sebo, graxa e couros, nem sempre foram realizadas da mesma forma, mudando ao longo do tempo ${ }^{8}$.

Apesar de muitos viajantes estrangeiros terem registrado as atividades das charqueadas, as melhores descrições do processo de produção do charque foram realizadas por três deles. Os franceses Nicolau Dreys (1839) e Louis Couty (1880) e o norte-americano Herbert Smith (1882) deixaram preciosos relatos sobre o processo de fabricação do charque nesses estabelecimentos, que resumiam-se em poucas etapas. A descrição que realizo nas próximas páginas foi extraída dos textos dos mesmos e, no caso em que outros autores forem mencionados, realizarei a devida referência'.

À chegada das tropas de gado na charqueada e sua permanência na mangueira seguiam-se o seu abate, o transporte do animal para a cancha, a esfolação, a despostação (esquartejamento), o retalhamento das carnes (charqueamento), o salgamento das mesmas, o empilhamento das mantas, o seu secamento nos varais e o posterior transporte por via fluvial para o porto de Rio Grande, onde a mercadoria seguia o rumo das margens do Atlântico. Após a fase de engorda, quando as reses pastavam nos vastos campos da região da campanha rio-grandense ou do norte do Uruguai, as tropas de gado (já vendidas ou a negociar) eram levadas por terra até Pelotas, distante muitas léguas daquelas estâncias. Durante todo o verão, até quase chegar o inverno do outro ano, algo entre 300 e 400 mil cabeças de gado eram abatidas nas mais de 30 charqueadas que pontilhavam as margens do São Gonçalo $e$ do Pelotas. Conforme as descrições de Herbert Smith e de Louis Couty, quando o gado chegava à charqueada ele era mantido por muitas horas em cercados que se chamavam mangueiras. Essas estruturas se afunilavam numa das extremidades, que se comunicava com um curral menor chamado mangueira de matança, capaz de conter trinta cabeças de gado juntamente cercadas. Tendo entrado todo o gado na mangueira de matança, a mesma era fechada. De acordo com Smith, esse recinto estava pavimentado com pedras lisas e escorregadias e chapas inclinadas para a extremidade oposta à entrada. Por fora da cerca, e rodeando-a, havia um passeio de tabuões por onde os trabalhadores se locomoviam à vontade a uma altura superior a do animal. Um dos bovinos aparecia no brete e era logo laçado por um escravo que esperava atento. Esse laço possuía sua extremidade presa a uma junta de bois que movimentavam um guincho $e$, mesmo que o animal resistisse, logo vinha a escorregar e deslizava próximo do cercado, onde o desnucador, um capataz treinado, o esperava com um punhal comprido e muito afiado.

\footnotetext{
${ }^{8}$ Tal fenômeno já foi evidenciado por Berenice Corsetti e Ester Gutierrez. Ver: CORSETTI, Estudo da charqueada escravista...; GUTIERREZ, Negros, charqueadas \& olarias...

${ }^{9}$ DREYS, Nicolau. Notícia descritiva da Província do Rio Grande do Sul. Porto Alegre: IEL, 1961. SMITH, Herbert. Do Rio de Janeiro a Cuiabá. S.l.: s.r., 1922, p. 134-142. COUTY, Louis. A erva mate e o charque. Pelotas: Seiva, 2000, p. 94-138. Uma exposição semelhante a que pretendo fazer foi realizada por Berenice Corsetti e Ester Gutierrez. Ver: CORSETTI, Estudo da charqueada escravista...; GUTIERREZ, Negros, charqueadas \& olarias...
} 
Após a queda de um novilho abatido era necessário retirá-lo do recinto para que a operação reiniciasse e outro animal fosse rapidamente introduzido no brete. $\mathrm{O}$ processo de transporte do boi para a cancha, ou seja, o espaço externo e contíguo ao local de abate onde as operações seguintes eram realizadas, foi descrito diferentemente na época de Dreys (década de 1820) e na de Smith e Couty (década de 1880). Conforme Dreys, após o novilho ter sido abatido, um guindaste, rodando sobre seu eixo, elevava o animal asfixiado e preso pelo laço para fora do cercado do curral e o transportava para a cancha ${ }^{10}$. Se nos anos 1820 a introdução do guindaste giratório foi inovadora, nos relatos da década de 1880, ele já não estava mais presente. Smith escreveu que após o novilho ser abatido, uma porta se abria quase que instantaneamente e o animal, que ainda urrava e apresentava contrações, caía sobre um carro ou vagão, onde era puxado por escravos, estando um deles a cavalo $^{11}$. Alguns charqueadores, como José Inácio da Cunha e Tomás José de Campos, possuíam trilhos instalados no pátio de suas charqueadas, onde o vagão deslizava carregando os animais abatidos até à cancha ${ }^{12}$.

Chegando à cancha, diversos escravos eram encarregados de executar as operações seguintes. A cancha ficava praticamente contígua à mangueira de matança e constituía-se num espaço circular com um piso de laje lisa e coberto por um telheiro ${ }^{13}$. Conforme Gutierrez, podiam existir duas canchas, uma de cada lado dos trilhos. Cada cancha comportaria de 20 a 40 animais. Quando chegava na cancha, o novilho era rapidamente derrubado do vagão por dois cativos ou puxado por uma corda fixada a uma das patas dianteiras, sendo então arrastado por um escravo a cavalo. Logo que era largado no piso da cancha, uma equipe de escravos esfolava o animal em poucos minutos ${ }^{14}$. Conforme Dreys, a disposição da cancha e da escoação dos resíduos era tão bem feita que após as operações quase não se detectava vestígios da matança ${ }^{15}$. Logo em seguida, outro grupo de escravos iniciava o esquartejamento do bovino. O espaço era rapidamente esvaziado a espera dos próximos animais abatidos. Toda a operação da despostação, segundo Couty, durava de cinco a seis minutos ${ }^{16}$.

Em um ou mais galpões, um grupo de escravos com suas facas devidamente afiadas esperava as partes do animal para dar início às etapas seguintes. Os pedaços que eram transportados até ali ficavam suspensos em suportes especiais, onde era feita a desossa. Os ossos eram separados e as carnes enviadas para outros escravos. Dava-se início à charquia, a operação mais delicada de todas. O objetivo era transformar os grandes pedaços de carne com formatos irregulares em mantas de 1,5 $\mathrm{cm}$ de espessura com superfícies de 1,50 metros de largura. Esta operação era realizada por alguns pares de experientes escravos, colocados um de cada lado diante

\footnotetext{
${ }^{10}$ DREYS, Notícia descritiva..., p. 133-134.

${ }^{11}$ SMITH, Do Rio de Janeiro a Cuiabá..., p. 135-142.

12 GUTIERREZ, Negros, charqueadas \& olarias..., p. 187-188. Inventário de Virgínia Louzada de Campos, n. 335, m. 23, 1851, Pelotas, $1^{\circ}$ cart. órfãos e provedoria (APERS); Inventário de José Inácio da Cunha, n. 600, m. 38, 1865, $1^{\circ}$ cart. de órfãos e ausentes, Pelotas (APERS).

${ }^{13}$ DREYS, Notícia descritiva..., p. 133-134.

${ }^{14}$ GUTIERREZ, Negros, charqueadas \& olarias..., p. 187-189.

${ }^{15}$ DREYS, Notícia descritiva..., p. 133-134.

${ }^{16}$ COUTY, A erva mate..., p. 97-112.
} 
da carne estendida sobre uma barra de madeira. De acordo com Dreys, após a retalhação, levavam-se as mantas de carne para outro galpão chamado "salgadeiro" 17 . Assim que as mantas eram entregues, alguns cativos colocavam-nas sobre mesas côncavas cheias de sal, onde os escravos salgadores as impregnavam com o produto ${ }^{18}$. Depois de salgada, a carne era empilhada no próprio galpão. Conforme Smith, o empilhamento era realizado em camadas, sendo uma de sal, outra de carne e assim por diante. As pilhas formavam uma espécie de cúpula de base quadrangular que diminuía no sentido da altura e chegava a muitos metros. Para comprimir a base da pilha com fim de torná-la o mais horizontal possível $e$ favorecer o restante do empilhamento recorria-se a mais ou menos cinco cativos que de pé, em cima das pilhas, e usando as mãos ou outras ferramentas conseguiam o resultado desejado. Uma pilha formada com as carnes de 200 bois media aproximadamente 5 metros de comprimento e de largura, com 0,8 metros de altura nas pontas e 1,3 metros no centro. O empilhamento possuía um duplo efeito de impregnar a carne com o sal e de escorrer os líquidos contidos nela por meio da própria pressão. Esse efeito era aumentado reempilhando-se as mesmas carnes no dia seguinte, de modo que as camadas de cima, tiradas primeiro, formavam a base da nova pilha. Em toda esta operação utilizava-se uma média de $10 \mathrm{~kg}$ de sal para cada animal, podendo a quantidade variar conforme o seu tamanho ${ }^{19}$.

Passados um dia ou dois, se o tempo estivesse suficientemente favorável, as carnes salgadas eram desempilhadas e transportadas para fora do galpão onde se iniciava a etapa do secamento. As mantas de carne eram estendidas nos varais - barras de madeira bastante longas que eram colocadas transversalmente a um metro e meio do solo, aproximadamente. No fim da tarde, as carnes eram amontoadas em vários pontos dos varais e cobertas com lonas. Encontrando um tempo com sol, esse processo levava de 5 a 6 dias. Segundo Couty, após o secamento a carne era colocada em uma pilha definitiva e separada em duas qualidades diferentes ${ }^{20}$. Conforme Dreys, cada boi podia dar, em média, de 4 a 5 arrobas de charque (60 a $75 \mathrm{Kg})^{21}$.

$\mathrm{O}$ charque era somente um dos produtos fabricados nas charqueadas. Muito antes dele ter se tornado mercadoria importante, o couro já ocupava um papel de destaque no circuito mercantil que envolvia o Rio Grande, as capitanias do Brasil e a Europa. O tratamento do couro nas charqueadas pelotenses também sofreu alterações ao longo do período analisado. Na primeira metade do oitocentos estacava-se o couro no chão para o seu secamento, dando-lhe um declívio para deixar correr as águas. Mas na época de Smith e Couty os couros eram banhados em tanques de salmoura, como se faziam nas charqueadas platinas. Ao sair da fossa, os couros eram amplamente polvilhados de sal e dobrados em dois, de maneira que os pelos ficassem para o lado de fora. Depois eram dispostos, um ao lado dos outros, em camadas de couros alternadas por camadas espessas de sal. Desta forma eram colocados em

\footnotetext{
${ }^{17}$ DREYS, Notícia descritiva..., p. 133-134.

${ }^{18}$ COUTY, A erva mate..., p. 105.

${ }^{19}$ GUTIERREZ, Negros, charqueadas \& olarias..., p. 189.

${ }^{20}$ COUTY, A erva mate...

${ }^{21}$ DREYS, Notícia descritiva..., p. 142.
} 
barracas especiais, onde formavam pilhas extensas, retangulares ou quadrangulares, $e$ de pouca elevação, contendo de 10 a 15 camadas expostas umas sobre as outras. Uma vez salgado e empilhado, o couro conservava-se por longo tempo e estava pronto para ser exportado para a Europa, onde se estimava muito o produto preparado desta forma, conhecido como couro salgado ${ }^{22}$.

Mudanças na forma do preparo dos sebos e das graxas também aconteceram. Estes dois produtos constituíam-se nas partes gordurosas do boi, sendo a graxa uma gordura mais fina e o sebo a mais grosseira. Sua utilidade era industrial, pois eram empregados na fabricação de sabão, velas e ceras, embora a graxa, muitas vezes, também fosse utilizada para fins comestíveis. Na época de Dreys, os ossos, a cabeça e as extremidades do animal eram colocados numa caldeira fervente, servindo, com os miolos e o tutano, à preparação da graxa, que era, depois, encerrada na bexiga e nos intestinos grossos, para ser comercializada. Chamo atenção para esse momento do preparo do produto pois, conforme Debret, era a única etapa em que viu mulheres escravas trabalhando no interior das charqueadas. Elas eram responsáveis por ensacar esses subprodutos, atividade que não exigia força ${ }^{23}$. Ainda de acordo com Dreys, as partes mais sebáceas eram socadas na mesma caldeira para comporem uns pães de sebo grosseiro, que também eram vendidos.

A grande inovação com relação à extração desses produtos foi a instalação das graxeiras a vapor, verificáveis nos inventários post-mortem a partir das décadas de 1840 e 1850. As graxeiras a vapor proporcionavam um melhor aproveitamento de todas as partes do animal, oferecendo subprodutos de melhor qualidade e produzidos em menor tempo. De acordo com Couty, para o preparo da graxa eram lançados cabeças, encéfalos, estômagos, corações e certas vísceras de 150 a 200 animais. O cozimento, feito a vapor de pressão, durava de 36 a 50 horas. Ao lado da caldeira, os proprietários colocavam pipas e barricas prontas para serem cheias. Algumas delas chegavam a medir 4 ou 5 metros de altura. Na elaboração do sebo, entravam os intestinos e as membranas envolventes do peritônio. O seu período de cozimento era menor que o da graxa. Esse era feito em cubas menores, de madeira grossa, reforçadas com aros de ferro, as quais tinham uma abertura lateral na parte de baixo, por onde o sebo escorria ${ }^{24}$.

\section{A Distribuição dos Escravos nas Unidades Produtivas do Charqueador}

Quais as características da escravidão nas charqueadas pelotenses? Para analisar como os escravos estavam distribuídos nas unidades produtivas do charqueador $e$ chegar o mais perto possível da divisão de funções dos mesmos cativos selecionei, entre os 45 inventários post-mortem de charqueadores que encontrei distribuídos entre os anos de 1831 e 1885, somente aqueles em que mais de $80 \%$ das ocupações dos escravos foram mencionadas no inventário, resultando em 17 documentos ${ }^{25}$.

${ }^{22}$ COUTY, A erva mate...

${ }^{23}$ DEBRET, Jean-Baptiste. Viagem pitoresca e histórica ao Brasil - Tomo I. São Paulo: EDUSP, 1972, p. 243.

${ }^{24}$ COUTY, A erva mate..., p. 124-127.

${ }^{25}$ No caso dos inventários com plantéis avaliados mais de uma vez (quando os bens do casal eram avaliados na morte de um cônjuge $e$, anos depois, o do viúvo) foram mantidos somente aqueles que 
Analisando tais fontes, proponho uma divisão em quatro grupos de atividade distintos, em que os escravos podiam estar separados: a) os ligados diretamente à produção do charque, trabalhando no interior dos estabelecimentos; b) os que eram empregados em atividades acessórias às charqueadas $e$ externas aos estabelecimentos; c) os artesãos especializados em algum ofício; d) os de serviço doméstico. Essa divisão não era rígida. É muito provável que em alguns momentos, no auge da matança, e conforme as necessidades do proprietário, os campeiros, marinheiros $e$ artesãos diversos fossem realocados para as tarefas no interior da charqueada ${ }^{26}$. No entanto, o fato de os mesmos serem classificados com suas respectivas ocupações nos inventários post-mortem merece ser levado em conta, pois demonstra que charqueadores, capatazes e avaliadores os distinguiam dessa forma.

a) Entre os trabalhadores da charqueada, verificavam-se os carneadores, descarneadores, charqueadores, tripeiros, salgadores, sebeiros, chimangos, graxeiros e serventes, além dos aprendizes. Esses escravos eram, sem dúvida, as engrenagens da charqueada. Na maior parte dos inventários, eles ficavam entre $40 \%$ e $65 \%$ de todo o plantel do proprietário, atingindo uma média geral próxima dos $56 \%$ (com o mínimo em $36 \%$ e o máximo em $90 \%$ do plantel de um charqueador). No interior deste grupo de escravos, os mais numerosos eram os carneadores - os especialistas em cortar as mantas de carne. Em alguns plantéis eles compunham a metade dos escravos desse grupo e em outros chegavam a $2 / 3$ do mesmo. Os segundos mais numerosos eram os escravos salgadores e os serventes, seguidos pelos chimangos (que trabalhavam o couro) e os graxeiros. Os serventes aparecem em alguns plantéis como "serventes de charqueada". Os menos comuns eram os tripeiros, os descarnadores e os sebeiros.

Observados com atenção, essas subocupações parecem revelar a própria transformação e especialização no interior das charqueadas. Carneadores e graxeiros aparecem nos inventários desde a década de 1810. Os serventes, os salgadores e os sebeiros só começam a aparecer a partir da década de 1820. Os primeiros chimangos discriminados como tal só surgem nos plantéis da década de 1840. Os escravos mais especializados como os tripeiros surgem somente nos inventários da década de 1850 $e$ os descarnadores na década de $1860^{27}$. Tal fenômeno não significa que as atividades executadas pelos tripeiros e descarnadores, por exemplo, não eram realizadas anteriormente, mas sugere que a intensificação das mudanças de ordem técnica passou a exigir cada vez mais o treinamento e a especialização de alguns

possuíam informações mais completas. Esta documentação encontra-se sob a guarda do Arquivo Público do Estado do Rio Grande do Sul (APERS). Uma análise mais aprofundada dessa documentação pode ser verificada em minha tese de doutorado. Ver: VARGAS, Pelas margens do Atlântico...

${ }^{26}$ Também é provável que esta divisão fosse menos rígida entre os menores plantéis, podendo os escravos exercer mais de uma função ao mesmo tempo. Mas o fato de eles serem avaliados nos inventários com uma especialização e declararem as mesmas quando informantes ou réus em processos-crime significa que havia um grau de especialização que precisa ser levado em conta. VARGAS, Pelas margens do Atlântico.... Uma análise neste sentido foi realizada anteriormente nos mencionados trabalhos de Corsetti e Gutierrez.

${ }^{27}$ Uma consideração semelhante foi feita por PESSI, Bruno S. A organização do trabalho escravo nas charqueadas pelotenses na segunda metade do século XIX. Anais da VIII Mostra de pesquisa do APERS. Porto Alegre: CORAG, 2010, p. 97-114. 
escravos do plantel, ao ponto de eles serem reconhecidos pelos avaliadores como experts naquele ofício.

Com relação ao treinamento é importante dar destaque aos "aprendizes". Eles estão ausentes nos inventários das décadas de 1810 a 1830, começando a aparecer somente na década de 1840 . Os aprendizes de carneador eram os mais numerosos, visto essa ser uma das atividades mais difíceis de ser executada na charqueada. Os aprendizes de salgador também estavam presentes nos plantéis e junto deles há os que somente foram definidos como "aprendiz". Eles também poderiam ser aprendizes de graxeiro, pois encontrei dois mestres graxeiros entre os escravos. Tal fenômeno revela uma preocupação do proprietário em treinar seu plantel para otimizar a produção, algo que apresentava traços de uma maior racionalização do trabalho ${ }^{28}$.

Com relação a isso há outro fator interessante. Os descarnadores, tripeiros, aprendizes e mestres estão presentes somente nos maiores plantéis, geralmente os acima de 70 escravos, mas, sobretudo, entre os inventariados com mais de 100 cativos. Seria a riqueza e o número de escravos pré-condição para uma especialização do plantel? Ou seria o contrário? Charqueadores com uma visão mais "avançada" de organização do trabalho na charqueada teriam maiores chances de enriquecer podendo assim ampliar seu plantel? Por falta de melhores indícios documentais esta questão deve ficar em aberto, mas creio que um fator devia complementar o outro.

Nos inventários das décadas de 1810 a 1840, a maioria dos documentos apresentava uma precária divisão do trabalho. O plantel menos especializado era o de Domingos Rodrigues (1818), cujos 42 escravos foram descritos com a ocupação "serviço da casa e da charqueada"29. Portanto, não havia uma distinção muito clara sobre as atividades dos cativos. Pode-se argumentar que foi desleixo do escrivão $e$ dos avaliadores ou que a feitura dos documentos da época não especificava essas ocupações. Entretanto, tais hipóteses não se verificam nos outros inventários da mesma época, como o de José Pinto Martins ${ }^{30}$. No entanto, como um divisor de águas, o inventário de Maria Augusta da Fontoura (1845) destoa dos outros de sua época ${ }^{31}$. Ela era esposa do charqueador Joaquim José de Assumpção. No seu plantel de 125 escravos, o número de aprendizes é muito maior que o dos outros. Havia 4 aprendizes de carneador e 3 de salgador, além de outros 3 denominados somente "aprendizes". Fora da charqueada havia 2 aprendizes de campeiros, 1 de carpinteiro e 1 de calafate. Talvez esse charqueador possuísse uma visão mais empresarial sobre a forma de organização do trabalho em sua unidade produtiva e possa ter influenciado os outros a seguirem o seu padrão de treinamento dos cativos desde a juventude. Seu filho homônimo herdou o estabelecimento paterno e tornou-se o Barão de Jarau. Se o pai apresentou uma fortuna mediana em sua época, o filho foi o charqueador mais rico de Pelotas na segunda metade do oitocentos, apresentando

\footnotetext{
${ }^{28}$ VARGAS, Pelas margens do Atlântico...

${ }^{29}$ Inventário de Domingos Rodrigues, n. 32, m. 2, 1818, Pelotas, $1^{\circ}$ cart. órfãos e provedoria (APERS).

${ }^{30}$ Inventário de José Pinto Martins, n. $354, \mathrm{~m} .15,1832,1^{\circ}$ cart. órfãos e provedoria, Rio Grande (APERS).

${ }^{31}$ Inventário de Maria A. da Fontoura, n. 514, m. 22, 1845, $1^{\circ}$ cart. órfãos e provedoria, Rio Grande (APERS)
} 
um patrimônio de 6.152:393\$500 réis, em $1895^{32}$. Portanto, pode-se supor que a herança de Joaquim para o filho não foi composta somente por bens materiais, mas também por conhecimentos técnicos e uma prática de organizar a produção e o trabalho escravo de forma mais especializada, ou seja, uma herança imaterial que deve ter auxiliado o filho a ampliar a fortuna do pai $^{33}$.

b) Outro grupo de escravos importante era formado por aqueles que realizavam tarefas acessórias à charqueada, sem ser diretamente ligadas à matança e fabricação do charque e dos subprodutos. Algumas delas estavam quase integradas ao estabelecimento. Os mais importantes eram os campeiros, encarregados de tratar das reses nos potreiros da charqueada antes do abate, e os marinheiros, que trabalhavam no transporte fluvial e marítimo dos produtos da charqueada. Muitos campeiros também eram empregados nas estâncias dos charqueadores, geralmente em outros municípios. No serviço do transporte terrestre havia os carreteiros e carroceiros. E trabalhando nas chácaras e lavouras dedicadas a abastecer a charqueada de alimentos havia os tafoneiros, roceiros e lavradores.

Mas nem todos os plantéis possuíam escravos desse grupo. Os marinheiros só estavam presentes entre os que tinham alguma embarcação e os campeiros eram mais comuns entre os que possuíam estâncias de criação. O mesmo serve para os roceiros, lavradores e tafoneiros, com relação às lavouras e chácaras. Na maioria dos inventários, os escravos desse grupo perfaziam de $10 \%$ a $15 \%$ dos plantéis, havendo casos com um mínimo de $2 \%$ e outros com um máximo de $32 \%$. A posse de tais cativos também podia indicar uma importante busca de autossuficiência das unidades produtivas no que diz respeito ao transporte fluvial e marítimo, ao abastecimento de alimentos para os cativos e de gado para a charqueada. Aníbal Antunes Maciel, por exemplo, era o charqueador com o maior número de escravos campeiros. Eles totalizavam 20 cativos com este ofício. Analisando seu inventário, percebe-se que o coronel Aníbal era o dono do maior rebanho entre os charqueadores. Ele possuía mais de 34 mil reses de criar pastando nas suas estâncias. $\mathrm{O}$ mesmo serve para a relação entre o número de marinheiros e o de embarcações ${ }^{34}$.

Nesse grupo também localizei aprendizes de campeiro e de marinheiro. Os aprendizes de campeiro eram muito jovens, tendo 12 ou 13 anos $^{35}$. Com relação aos marujos, destaco os "aprendizes de marinheiro de brigue". E aqui é possível fazer duas considerações. A primeira é de que, assim como outros ofícios, também havia treinamento para ser marinheiro dentro da própria charqueada. A segunda é a de que havia uma separação entre os marinheiros de um iate e os que podiam ultrapassar

${ }^{32}$ Inventário da Baronesa do Jarau, n. 187, m. 6, 1895 , $2^{\circ}$ cartório do cível, Pelotas (APERS).

${ }^{33}$ No entanto, esta especialização, que se intensificou a partir de meados dos oitocentos, não foi linear $e$ evolutiva e nem envolveu todos os escravos e plantéis. Um plantel com aprendizes e descarnadores também era composto de escravos sem um ofício definido ou escravos com dois ofícios, como alfaiate/ salgador ou carpinteiro/carneador. Algo até certo ponto compreensível para uma empresa que funcionava somente durante seis a sete meses ao ano. Portanto, é possível que alguns charqueadores tenham especializado o seu plantel servindo de exemplo para outros, mas tal fenômeno apresentou um processo gradativo e certamente cheio de percalços.

${ }^{34}$ Inventário de Felisbina da S. Antunes, n. 68, m. 2, Pelotas, Cartório do Civel e Crime; Inventário de Anibal A. Maciel, n. 815, m. 48, 1875, $1^{\circ}$ cart. órfãos e provedoria, Pelotas (APERS).

${ }^{35}$ Como será evidenciado a seguir, existiam crianças escravas classificadas como "campeiras" com idades menores do que os 12 anos. 
esta barreira, podendo estar a bordo de um brigue, uma embarcação de maior porte, utilizada em viagens marítimas de longo curso e que exigia um maior treinamento. A presença de escravos com o apelido de "capitão" sugere que os mesmos deviam treinar esses aprendizes.

c) Outro grupo importante no plantel dos charqueadores eram os escravos artesãos ou com ofícios especializados. Entre eles existiam carpinteiros, alfaiates, sapateiros, pedreiros, tanoeiros, lombilheiros, marceneiros, oleiros, correeiros e ferreiros. Considerei que as mulheres costureiras também deveriam fazer parte desse grupo. Eles podiam compor entre $3 \%$ e $12 \%$ do plantel, com uma média de $6 \%$. Os carpinteiros eram os mais numerosos, seguidos dos pedreiros, sapateiros e alfaiates. Esse grupo era muito importante nas charqueadas, pois seus serviços eram utilizados para reformar o próprio estabelecimento e seus equipamentos, visto que as instalações deviam sofrer uma manutenção anual. Além do mais, como já mencionei, suas atividades também eram importantes na construção civil $e$ na fabricação de vestimentas para os escravos. A possibilidade de alugar os seus trabalhos nas entressafras também os tornava um grupo importante no interior das senzalas. Entre os mesmos também se verifica um número significativo de aprendizes, mas esses já estavam presentes nos inventários dos fins do século XVIII e início do XIX e não causam muita surpresa, pois tais ofícios mecânicos sempre foram praticados por escravos, envolvendo relações entre mestres e aprendizes. Outro fator importante do grupo é que muitos escravos exerciam esse ofício combinado com outro que dizia respeito a alguma tarefa realizada no interior da charqueada, surgindo cativos discriminados como pedreiro/ carneador, servente/ sapateiro, graxeiro/ carpinteiro, alfaiate/ salgador/ tanoeiro/ tripeiro, entre outros.

d) $\mathrm{O}$ último grupo reúne os escravos de serviço doméstico ou ligados a atender às necessidades mais pessoais do charqueador e de sua família. Entre os mesmos encontram-se as mucamas, lavadeiras, cozinheiras, engomadeiras, copeiros e serviços domésticos. Também coloquei nesse grupo os boleeiros, visto conduzirem seus senhores diariamente pela cidade. Como se pode perceber é nesse grupo que as mulheres se faziam mais representadas. As tarefas realizadas por esse grupo também eram essenciais para o senhor, mas a sua quantidade também devia revelar um maior status social. É possível que algumas das cozinheiras aqui elencadas trabalhassem nas charqueadas preparando a comida para os demais cativos, e que alguns serventes colocados no primeiro grupo aqui analisado estivessem presentes nesse, conforme se percebe nos inventários. O trânsito de escravos entre as instalações da charqueada e a casa do senhor devia ser corrente, mesmo quando esse residia na cidade. Apesar de seus plantéis apresentarem uma razão de sexo muito alta (os homens perfaziam $82 \%$ dos escravos) em mais de $85 \%$ deles havia crianças, o que indica a existência de laços familiares, e, portanto, do contato entre as distintas senzalas (charqueada, estâncias e chácaras) e a casa do senhor, mas também, possivelmente, das escravas do charqueador com libertos e homens livres pobres ${ }^{36}$.

A observação individualizada de alguns plantéis auxilia a perceber a divisão do trabalho no interior das unidades produtivas. A análise da escravaria do casal José Antônio Moreira e Leonídia Gonçalves (o Barão e a Baronesa do Butuí) serve para

${ }^{36}$ Ver: VARGAS, Pelas margens do Atlântico... 
complexificar esta análise, pois seus inventários trazem informações detalhadas e não existentes para outros charqueadores ${ }^{37}$. A Baronesa faleceu em 1867 e o Barão em 1877. Em 1867 foram arrolados 132 escravos e, em 1877, 158. No interior do segundo processo foi anexada a cópia dos registros de matrícula dos escravos do inventariado, realizadas em 1872/ 1873, com detalhes sobre a idade, naturalidade, profissão, estado civil e filiação de 142 cativos $^{38}$. O diferencial da documentação envolvendo o Barão de Butuí é que o escrivão anotou o local em que moravam e trabalhavam os respectivos escravos, algo não verificável com tamanhos detalhes para os outros charqueadores. Entretanto, todos eles foram matriculados como "serviço de charqueada". Como no inventário de 1867 os mesmos escravos tiveram seus ofícios discriminados, cruzei os dois documentos para compreender como o plantel do casal estava dividido entre as diferentes unidades produtivas do charqueador.

A partir da cópia das matrículas de 1872, o plantel de escravos do Barão de Butuí estava dividido da seguinte forma: residentes na cidade (27), na charqueada (79), na Serra dos Tapes (3), na Estância de Poncho Verde, localizada no município de Bagé (18), a bordo da Barca Pombinha (5), do Patacho Moreira (3), do Iate Santa Rita (4) e do late Novo São Jerônimo (3). A partir dessa divisão já é possível perceber que $55 \%$ do plantel residia na charqueada, $19 \%$ na cidade, onde o Barão possuía dois sobrados e diversas casas e terrenos. Na estância e na chácara nos Tapes estavam $15 \%$ deles e a bordo de alguma embarcação encontravam-se $10 \%$.

$\mathrm{Na}$ charqueada havia 68 homens adultos e 2 mulheres adultas, 5 meninos e 4 meninas menores de 12 anos. As crianças eram filhas das escravas Carlota (2), que não pertencia mais ao plantel, Regina (4) que trabalhava na charqueada no serviço doméstico, e Agostinha (3), que era engomadeira e morava na cidade ${ }^{39}$. Das crianças, todas não possuíam ofício, com exceção do menino Norberto que, com 12 anos, já era servente de charqueada e devia estar aprendendo algum ofício mais especializado. Dos homens adultos, um prestava serviços domésticos e outro era o cozinheiro da charqueada. Os 66 restantes foram definidos como "servente de charqueada". Mas cruzando com os nomes dos mesmos com os citados no inventário da Baronesa, de 1867, é possível discriminar sua função no estabelecimento. Desses 66 escravos, 19 eram carneadores, 11 eram chimangos, 10 eram salgadores e 2 eram descarnadores. Havia também 1 graxeiro/ carpinteiro e 1 chimango/ alfaiate. Para os outros 22 não foi possível definir a especialização, pois a informação não foi mencionada no documento. Portanto, como afirmei anteriormente, a razão de sexo no estabelecimento de charqueada era maior que a do plantel inteiro do

\footnotetext{
${ }^{37}$ Inventário do Barão e da Baronesa de Butuí. Pelotas, n. 647, m. 41, 1867/1877, $1^{\circ}$ cart. órfãos e provedoria, Pelotas (APERS).

${ }^{38}$ Sobre a legislação que ordenava a feitura dos registros das matrículas dos escravos e as possibilidades de pesquisa com esta documentação ver: SLENES, Robert. "O que Rui Barbosa não queimou: novas fontes para o estudo da escravidão no Século XIX". Estudos Econômicos, vol. 13, n. 1, jan./ abr. 1983, p. 117-149.

${ }^{39}$ Não foi possível saber quem eram os pais das crianças. Sobre os limites do uso de inventários postmortem para estudo da família escrava em Pelotas, ver: PESSI, Bruno S. "A família escrava em Pelotas na segunda metade do século XIX a partir de inventários post-mortem". Anais da IX Mostra de pesquisa do APERS. Porto Alegre: CORAG, 2010, p. 245-264. Para o estudo da família escrava em Pelotas na primeira metade do século XIX, ver: PINTO, A benção compadre...
} 
charqueador. Enquanto no primeiro somava-se $97 \%$ de homens (contando apenas os adultos) ou $92 \%$ (somando as crianças), no plantel total tinha-se $92 \%$ e $87 \%$, respetivamente.

Na estância do Ponche Verde, por exemplo, havia 11 homens adultos, 3 mulheres adultas, 3 meninas e 1 menino. Dos 11 homens, 10 eram campeiros e 1 cozinheiro. Entre as mulheres havia 1 costureira, 1 roceira e 1 doméstica. Observe-se que na estância, a diferença dos sexos era menor ( $78 \%$ entre os adultos), embora ainda fosse alta. Os 3 escravos da Serra dos Tapes eram roceiros e os 15 escravos nas embarcações, com exceção do cozinheiro José, eram todos marinheiros. Dos 27 escravos residentes na cidade, havia 18 homens adultos, 5 mulheres adultas, 3 meninos e 1 menina. Entre os mesmos, estavam 2 escravos alfaiates, 2 carpinteiros, 4 pedreiros, 1 sapateiro, 2 copeiros, 2 cozinheiros, 1 boleeiro, 3 costureiras, 2 engomadeiras, 1 lavadeiro, 2 serventes e 1 campeiro que estava na cidade para ser vendido. É muito provável que os escravos com ofícios artesanais que viviam na cidade fossem alugados, auferindo significativos lucros ao senhor.

Portanto, verificam-se crianças na charqueada, na cidade e na estância em Bagé. Creio tratar-se de três núcleos escravistas distintos, muito embora, como já mencionei, havia trânsito entre os mesmos. É provável que os pais destas 17 crianças estivessem trabalhando nos mesmos núcleos, muito embora os filhos da escrava Agostinha, residente na cidade, estivessem na charqueada. Esses 17 escravos num plantel de 142 significavam que $12 \%$ do total do plantel era renovado com as chamadas "crias de casa". Analisando somente a charqueada, esse valor mantém-se em $11 \%$. Tratava-se de um índice superior à média total de crianças de 6,9\% apresentada para todas as charqueadas entre os anos 1866 e 1885, que será analisado mais adiante.

Mas qual o motivo de o plantel do Barão do Butuí possuir um número de crianças bem acima da média total dos charqueadores? Uma explicação possível é que um dos fatores que potencializava a reprodução natural seria a posse de estâncias, chácaras $e$ a presença de escravas domésticas, uma vez que, como foi demonstrado, havia somente duas mulheres na charqueada. Aqueles proprietários que possuíam somente a charqueada ( $e$ isso foi muito comum) tendiam a possuir um número bem menor de mulheres, visto que seu serviço na charqueada era pouco empregado ${ }^{40}$. Portanto, privilegiados eram os escravos que conseguissem circular para além das charqueadas, para, quem sabe, ir ao encontro de uma das demais cativas do senhor. O número de mulheres adultas fora da charqueada era 4 vezes superior ao número de mulheres na charqueada $e$ tais contatos $e$ vínculos afetivos pareciam influir sobre o maior ou o menor número de crianças cativas nos plantéis. Contudo, o círculo de relações afetivas dos escravos não se restringia às senzalas do charqueador, podendo estenderse para fora do cativeiro, como muitos trabalhos já demonstraram ${ }^{41}$.

Portanto, a análise do plantel do Barão de Butuí é um bom exemplo de como um charqueador rico dividia a sua escravaria. É necessário destacar que $85 \%$ dos cativos

\footnotetext{
${ }^{40}$ VARGAS, Pelas margens do Atlântico...

${ }^{41}$ MATHEUS, Marcelo S. Fronteiras da liberdade: escravidão, hierarquia social e alforria no extremo sul do Império do Brasil. São Leopoldo: Oikos; UNISINOS, 2012. SLENES, Robert. Na senzala uma flor: esperanças e recordações na formação da família escrava - Brasil - Sudeste, século XIX. Rio de Janeiro: Nova Fronteira, 1999. MATTOS, Hebe. Das cores do silêncio: os significados da liberdade no Sudeste escravista (Brasil, século XIX). Rio de Janeiro: Arquivo Nacional, 1995.
} 
arrolados nas matrículas eram comprados (como a fonte indica). Com relação aos seus valores (mas sem levar em conta as idades) os mais caros eram os carneadores, com uma média de 1:420\$. Ter bons escravos carneadores era fundamental para a produtividade de uma charqueada. A partir da década de 1870, os charqueadores começaram a pagar premiações em dinheiro para os escravos que ultrapassassem a meta diária de novilhos carneados. Os carneadores foram os que mais ganharam com a introdução desse mecanismo, conseguindo alforriar-se mais facilmente que os demais companheiros de cativeiro ${ }^{42}$. Sua habilidade era tamanha que causou certa admiração no viajante Friedrich von Weech, que deixou registrado, por volta de 1820:

É obra de poucos minutos agarrar o animal, matá-lo, esticá-lo e fracioná-lo e estamos convencidos de que 60 açougueiros europeus não estão em condições de competir com 20 peões do Rio Grande do Sul. Tais homens, dedicando-se somente a este trabalho desde a mais tenra juventude, atingem nele uma prática tão extraordinária, que podem chegar a enviar ao salgadeiro, num único dia, de 70 a 80 bois. $^{43}$

Depois dos carneadores, os mais valorizados eram os copeiros (1:400\$), os cozinheiros (1:400\$), os campeiros (1:340\$), os salgadores (1:100\$) e os carpinteiros (1:000\$). O alto valor dos cozinheiros e copeiros demonstra os gastos de Butuí com os escravos domésticos, além da sua preocupação em investir na distinção social, o que denota o comportamento de uma família de elite. É necessário também referendar que somente $55,6 \%$ do plantel concentrava-se na charqueada. Portanto, para atuar com sucesso em outras atividades econômicas, como a criação de animais (a maior parte dos charqueadores não possuía estâncias) e o alto comércio, os charqueadores necessitavam de uma extensa mão de obra. Isso ajuda a compreender porque os plantéis dos 12 charqueadores mais ricos de Pelotas na segunda metade do oitocentos (aqueles que legaram mais de 50 mil libras esterlinas em seus inventários) possuíam uma média de escravos bem acima dos menos ricos (115 cativos contra 56 da média geral). Eles possuíam mais escravos com especializações em diferentes áreas. Nesse sentido, o tamanho da escravaria era diretamente proporcional à riqueza acumulada pelo charqueador e a amplitude de seus investimentos ${ }^{44}$.

Analisando o trabalho cativo nas charqueadas, Fernando Henrique Cardoso formulou a tese da "economia de desperdício" nesses estabelecimentos. Tal afirmação sustentava-se no fato de que a safra nas charqueadas durava em torno de 6 a 7 meses (novembro a maio) e que fora desse período a escravaria encontrava-se ociosa. Inspirado em Louis Couty, ele afirmou que numa empresa capitalista, com o término

\footnotetext{
${ }^{42}$ VARGAS, Pelas margens do Atlântico...

${ }^{43}$ WEECH, Friedrich Von. A agricultura e o comércio do Brasil no sistema colonial. São Paulo: Martins Fontes, 1992, apud OGNIBENI, Denise. Charqueadas pelotenses no século XIX: cotidiano, estabilidade e movimento. Tese (Doutorado em História). Pontifícia Universidade do Rio Grande do Sul. Porto Alegre, 2005, p. 132.

${ }^{44}$ VARGAS, Pelas margens do Atlântico...
} 
da matança, os empregados seriam dispensados e recontratados na próxima safra, enquanto que nas charqueadas os senhores eram obrigados a manter o sustento de seus plantéis improdutivos por mais um semestre $e^{45}$. Berenice Corsetti e Ester Gutierrez já refutaram essa afirmação, pois havia uma série de atividades para além das charqueadas em que os escravos podiam ser empregados ${ }^{46}$. Além da charqueada, muitos empresários também possuíam olarias, algo que não era privilégio dos charqueadores mais ricos. Somavam-se às mesmas as carpintarias, ferrarias, fábrica de curtumes, de colas ou estaleiros que podiam compor o patrimônio de outros charqueadores. Os escravos também podiam ser alugados e empregados em atividades para reformar a charqueada. Nas chácaras e datas de terras de matos o trabalho cativo também era importante. Dali provinha parte da alimentação dos cativos e um excedente para ser comercializado, mas também a madeira para o forno das graxeiras à vapor e das olarias. Estudando um importante charqueador da época, Carla Menegat também constatou que os extensos pomares presentes nas propriedades permitiam que parte da escravaria tivesse seus serviços direcionados para a produção de alimentos, as olarias, as fábricas de sebo $e$ velas $e$ as atafonas. Analisando as cartas escritas pelo charqueador, a autora verificou que o empresário deixava claro aos capatazes a importância da produção de alimentos, recomendando que fosse muito bem cuidada e que se vigiasse a escravaria. A plantação de mandioca tinha em suas terras a dupla função de manter os escravos ocupados e de prover sua alimentação. Ela era um apêndice importante da charqueada, além de permitir as negociações do excedente ${ }^{47}$.

\section{Um Perfil dos Trabalhadores Cativos}

Ainda é necessário realizar uma análise mais aprofundada do perfil das escravarias dos charqueadores pelotenses. A análise dos mesmos 48 inventários post-mortem de charqueadores (entre 1831 e 1885) que, quando faleceram, ainda possuíam seus estabelecimentos, ajuda a definir alguns fatores a esse respeito. Os documentos reúnem 2.732 escravos, mas nem todos trazem as informações de ocupação, idade, naturalidade e preço. No que diz respeito ao sexo dos escravos tem-se 440 mulheres $e$ 2.290 homens (2 não tiveram a informação identificada), o que resulta numa alta razão de sexo de 520 homens para cada 100 mulheres. No entanto, esse era o índice referente ao plantel total dos senhores (somando escravos da charqueada com os domésticos, marinheiros, campeiros, entre outros) e não aos que trabalhavam exclusivamente na charqueada. Como foi visto anteriormente, o número de homens com relação às mulheres no trabalho da charqueada era maior que o do plantel geral.

Para analisar o preço dos escravos das charqueadas selecionei somente os cativos adultos (incluí nessa faixa os que tinham entre 15 e 40 anos) e excluí todos aqueles avaliados como "doentes", "quebrados" ou com alguma anotação dos avaliadores

${ }^{45}$ CARDOSO, Fernando Henrique. Capitalismo e escravidão no Brasil meridional: o negro na sociedade escravocrata do Rio Grande do Sul. 2. ed. Rio de Janeiro: Paz e Terra, 1977.

${ }^{46}$ CORSETTI, Estudo da charqueada escravista...; GUTIERREZ, Negros, charqueadas \& olarias...

${ }^{47}$ MENEGAT, Carla. O tramado, a pena e as tropas: família, política e negócios do casal Domingos José de Almeida e Bernardina Rodrigues Barcellos (Rio Grande de São Pedro, Século XIX). Dissertação (Mestrado em História). Universidade Federal do Rio Grande do Sul. Porto Alegre, 2009, p. 147. 
que fizesse diminuir o seu valor ${ }^{48}$. Também converti os valores anuais de mil réis para libras esterlinas calculando as médias quinquenais ${ }^{49}$. A partir do Gráfico 1 percebe-se que até 1860 o preço das mulheres acompanhou o dos homens, para estacionar na década de 1860 e sofrer uma queda brusca após a Lei do Ventre-Livre (1871). Enquanto isto, os preços dos escravos homens mantiveram-se em ascensão até atingir os 1:600\$ (valor na moeda brasileira) em 1861-1865, para depois iniciar uma queda. $\mathrm{Na}$ década de 1880, quando a escravidão já estava condenada, os valores dos escravos de ambos os sexos encontravam-se num notável declínio (além disso, neste último período, não havia mulheres sadias nos inventários com informações do preço e da idade). Os índices também demonstram que no período em que o tráfico esteve vigente, mesmo que considerado ilegal pela Lei de 1831, os preços dos escravos mantiveram-se relativamente baixos e estáveis.

\section{GRÁFICO 1}

\section{PREÇO DOS ESCRAVOS ADULTOS (DE 15 A 40 ANOS) E SADIOS NAS CHARQUEADAS DE PELOTAS (1831-1885) (EM LIBRAS ESTERLINAS) ${ }^{50}$}

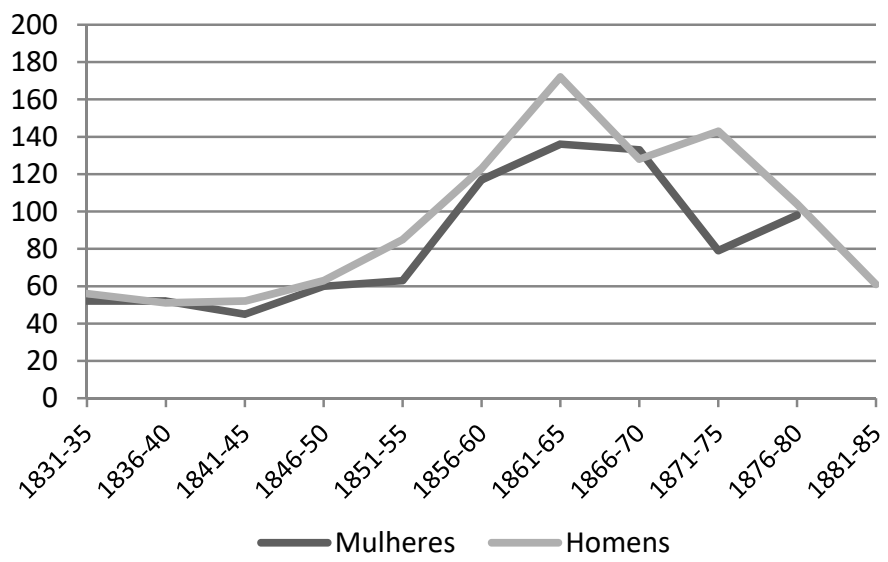

Para refinar melhor a análise destes dados separei os inventários em três períodos distintos. O primeiro elenca inventariados antes da Lei Eusébio de Queiroz, o segundo reúne cativos inventariados durante a fase de grande ascensão dos preços dos escravos adultos nas charqueadas de Pelotas e o terceiro reúne os inventariados durante a fase da queda dos mesmos até o fim da escravidão. Analisando a Tabela 1 percebe-se que a média de escravos foi decrescente ao longo de todo o período, enquanto a razão de sexo aumentou, chegando a 850 escravos homens para cada

\footnotetext{
${ }^{48}$ Eliminei da análise duas cativas de Inácio Rodrigues Barcellos avaliadas em 1863. Desconheço o motivo, mas os seus valores em mil réis correspondiam a $1 / 5$ do da grande maioria das mulheres cativas do mesmo período, o que causaria uma grande distorção na curva "1861-1865" do gráfico.

49 Juntei os anos 1831-1835 a 1836-1840 porque como o Judiciário esteve paralisado em Pelotas durante a Guerra dos Farrapos, existem poucos processos para o período.

${ }^{50}$ Fonte: Inventários post-mortem dos cartórios de Pelotas (1831-1885) (APERS).
} 
100 mulheres nos últimos decênios ${ }^{51}$. Ester Gutierrez defendeu que não houve redução nos plantéis dos charqueadores ao longo do período, pois a média da década de 1880 teria sido superior à média de todas as décadas anteriores ${ }^{52}$. No entanto, incorporando uma quantidade maior de inventários de charqueadores entre 1850 e 1884, Bruno Pessi demonstrou que embora os indicadores apresentassem oscilações houve uma diminuição dos $\operatorname{mesmos}^{53}$. De fato, de acordo com os inventários que pesquisei $e$ a ampliação da escala para uma maior duração temporal (estabelecendo para isso períodos analíticos de 15 a 20 anos), é possível perceber que a média dos plantéis dos charqueadores caiu ao longo dos anos. Observando os mesmos inventários por décadas, percebi que nos anos 1840 a média era de 65 escravos por charqueada. Na década de 1850 , esta média cai bastante, chegando a 51 cativos. Na década de 1860 ela volta a subir para 59 escravos. Na década de 1870 cai para 55 cativos e entre 1881 e 1885, apresenta uma média de 42 escravos - a menor de todo o período.

TABELA 1

NÚMERO DE ESCRAVOS E RAZÃO DE SEXO POR PERÍODO (1831-1885)

\begin{tabular}{ccccc}
\hline & $\mathbf{1 8 3 1 - 1 8 5 0}$ & $\mathbf{1 8 5 1 - 1 8 6 5}$ & $\mathbf{1 8 6 6 - 1 8 8 5}$ & Total \\
\hline INVENTÁRIOS & 15 & 19 & 14 & 48 \\
ESCRAVOS & $1.016^{*}$ & $1.022^{*}$ & 694 & 2.732 \\
MÉDIA POR INV. & 67,7 & 53,8 & 49,5 & 56,9 \\
HOMENS & $830(81,7 \%)$ & $839(82 \%)$ & $621(89,4 \%)$ & 2.290 \\
MULHERES & 185 & 182 & 73 & 440 \\
RAZÃO DE SEXO & 448 & 461 & 850 & 520 \\
\hline
\end{tabular}

Fonte: Inventários post-mortem dos cartórios de Pelotas (1831-1885) (APERS).

* Um cativo não teve o sexo identificado.

No entanto, se os charqueadores estavam sofrendo uma diminuição na média dos seus plantéis, a maior proporção de homens escravos em relação às mulheres escravas ao longo do período demonstra que novos cativos homens continuavam sendo comprados mesmo após o fim do tráfico, mantendo o desequilíbrio dos sexos. Tais negócios se davam em detrimento dos pequenos escravistas de Pelotas, que lentamente foram perdendo seus cativos para os charqueadores, além dos proprietários de outros municípios do interior. Portanto, não é adequado falar em uma crise geral de braços no setor, mas sim, numa crise que afetou um grupo de charqueadores, mas não afetou outro, pois nem todos os empresários conseguiram

\footnotetext{
${ }^{51}$ Estabelecendo uma análise de 5 em 5 anos, Bruno Pessi percebeu que entre 1850-1854 e 1880-1884 a média caiu de 59,5 para 44,3 cativos por charqueador. Contudo, neste meio tempo, elas oscilaram bastante, chegando a 81,2 escravos em 1865-1869 e 42,9 escravos em 1870-1874. PESSI, "A família escrava em Pelotas...", p. 74.

${ }^{52}$ GUTIERREZ, Negros, charqueadas \& olarias..., p. 178.

${ }^{53}$ PESSI, O impacto do fim do tráfico...
} 
contornar a falta de escravos pós $1850^{54}$. Além disso, também é possível verificar que a Lei do Ventre Livre (1871) retirou o interesse dos charqueadores em repor os seus plantéis com mulheres cativas, colaborando com a maior diminuição do número de escravas em termos absolutos, se comparadas aos homens.

Na Tabela 2 separei os cativos em 4 faixas etárias. O foco principal foi definir a representatividade dos escravos adultos nos plantéis ao longo do tempo, tendo elencado nessa categoria os escravos de 15 a 40 anos, como já disse. Decidi separar as crianças em dois grupos, tendo como critério a primeira idade em que elas foram classificadas com um ofício de trabalho. Como o pequeno Clemente, de 8 anos, foi arrolado como "campeiro" do charqueador João Simões Lopes escolhi essa idade como um divisor ${ }^{55}$. A Tabela demonstra que a média de escravos adultos entre os plantéis apresentou uma grande queda, ao mesmo tempo em que a razão de sexo quase dobrou do primeiro para o segundo período, reforçando o que foi dito acima. $\mathrm{O}$ número alto de homens idosos no primeiro período indica a intensidade do tráfico atlântico na primeira metade do XIX. Além disso, analisando em conjunto os indicadores de razão de sexo entre os idosos (956 no primeiro período e 2.476 no último) com a ainda significativa presença de homens adultos entre 1866-1885, se pode verificar a permanência dos efeitos do tráfico (refiro-me ao grande desequilíbrio entre os sexos), dessa vez juntamente com o comércio de cativos inter $e$ intraprovincial, mesmo às vésperas do fim da escravidão. Além disso, o grande aumento da razão de sexo entre as crianças $\mathrm{B}$ no último período indica que as mesmas também estavam presentes no circuito mercantil interno. Analisando os mesmos dados ainda é possível perceber que no último período os escravos idosos somavam quase a metade do plantel dos senhores, apresentando, como em outras regiões, um envelhecimento do plantel dos charqueadores.

\footnotetext{
${ }^{54}$ VARGAS, Jonas. "Das charqueadas para os cafezais? O tráfico interprovincial de escravos envolvendo as charqueadas de Pelotas (RS) entre as décadas de 1850 e 1880". In: XAVIER, Regina L. (org.). Escravidão e liberdade: temas, problemas e perspectivas de análise. São Paulo: Alameda, 2012.

${ }^{55}$ Pesquisando o perfil dos escravos traficados para o Rio Grande do Sul, Gabriel Berute localizou uma grande quantidade de crianças e jovens. Para o autor, tal perfil se explica pelo fato de que o ofício de campeiro era ensinado a escravos bem jovens, visto as dificuldades de se acostumar com os cavalos e exercer o ofício com destreza. BERUTE, Gabriel Santos. "O comércio de africanos ladinos e crioulos: Vila do Rio Grande (1812-1822)”. História Unisinos, vol. 10, 2006, p. 259-272.
} 
TABELA 2

FAIXA ETÁRIA E SEXO DOS ESCRAVOS DOS CHARQUEADORES (1831-1885)

\begin{tabular}{|c|c|c|c|c|c|}
\hline & SEXO & 1831-1850 & 1851-1865 & $1866-1885$ & Total \\
\hline \multirow{2}{*}{$\begin{array}{c}\text { Adultos } \\
\text { De } 15 \text { a } 40 \\
\text { anos }\end{array}$} & $\mathbf{M}$ & $419(82,9 \%)$ & $445(90,1 \%)$ & $228(88,7 \%)$ & 1.092 \\
\hline & $\mathbf{F}$ & $86(17,1 \%)$ & $49(9,9 \%)$ & $29(11,3 \%)$ & 164 \\
\hline \multicolumn{2}{|c|}{ Média por invent. } & 33,6 & 26 & 18,3 & 26,1 \\
\hline \multicolumn{2}{|c|}{ Razão de Sexo } & 487 & 908 & 786 & 665 \\
\hline \multicolumn{2}{|c|}{ SUBTOTAL } & $\begin{array}{c}505^{*} \\
(49,7 \%)\end{array}$ & $\begin{array}{c}494 \\
(48,4 \%)\end{array}$ & $\begin{array}{c}257 \\
(37,1 \%)\end{array}$ & $\begin{array}{c}1.256 * \\
(45,9 \%)\end{array}$ \\
\hline \multirow{2}{*}{$\begin{array}{c}\text { Crianças A } \\
\text { De } 1 \text { mês a } 7 \\
\text { anos }\end{array}$} & $\mathrm{M}$ & 24 & $21^{*}$ & 12 & 57 \\
\hline & $\mathrm{F}$ & 21 & 21 & 8 & 50 \\
\hline \multirow{2}{*}{$\begin{array}{c}\text { Crianças B } \\
\text { De } 8 \text { a } 14 \text { anos }\end{array}$} & M & 28 & 12 & 20 & 60 \\
\hline & $\mathrm{F}$ & 20 & 10 & 8 & 38 \\
\hline \multicolumn{2}{|c|}{ SUBTOTAL } & $93(9,1 \%)$ & $64(6,2 \%)$ & $48(6,9 \%)$ & $205(7,4 \%)$ \\
\hline \multirow{2}{*}{$\begin{array}{c}\text { Idosos } \\
\text { Acima de } 41 \text { anos }\end{array}$} & M & 239 & 231 & 322 & 792 \\
\hline & $\mathrm{F}$ & 25 & 27 & 13 & 65 \\
\hline \multicolumn{2}{|c|}{ SUBTOTAL } & $\begin{array}{c}265^{*} \\
(26,2 \%)\end{array}$ & $\begin{array}{c}258 \\
(25,3 \%)\end{array}$ & $\begin{array}{c}335 \\
(48,2 \%)\end{array}$ & $\begin{array}{c}858 \\
(31,4 \%)\end{array}$ \\
\hline \multicolumn{2}{|c|}{ Idade não identificada } & $153(15 \%)$ & $206(20,1 \%)$ & $54(7,8 \%)$ & $413(15,1 \%)$ \\
\hline \multicolumn{2}{|l|}{ TOTAL } & $1.016 *$ & $1.022 *$ & 694 & 2.732 \\
\hline
\end{tabular}

Fonte: Inventários post-mortem dos cartórios de Pelotas (1831-1885) (APERS) * Um cativo não teve o sexo identificado

A Tabela 3 busca investigar o percentual de africanos nos plantéis dos charqueadores. Em 1833, 67,4\% dos 5.623 escravos recenseados em Pelotas eram africanos - índice comparável às plantations açucareiras e cafeeiras do Brasi ${ }^{56}$. Os dados apresentados confirmam essa tendência nos inventários entre 1831 e 1850, quando $67,8 \%$ dos escravos com informações eram africanos. Entre 1851 e 1865, esse índice diminui apenas $5,6 \%$, vindo a apresentar uma grande queda somente no último período, como seria de se esperar. Dos 252 escravos com informações sobre sua naturalidade entre 1875 e 1885, 101 (40\%) eram africanos. Assim como nas outras tabelas, a razão de sexo também aumenta ao longo de todo o período,

\footnotetext{
${ }^{56}$ Ver, por exemplo, SALLES, Ricardo. E o vale era escravo: Vassouras, século XIX. Senhores e escravos no coração do Império. Rio de Janeiro: Civilização Brasileira, 2008. OLIVEIRA, Mônica Ribeiro de. Negócios de famílias: mercado, terra e poder na formação da cafeicultura mineira (1780-1870). Bauru: EDUSC; Juiz de Fora: Funalfa, 2005. BARICKMAN, Bert. "E se a casa-grande não fosse tão grande? Uma freguesia açucareira do Recôncavo Baiano em 1835". Afro-Ásia, n. 29/30, 2003, p. 79-132. LUNA, Francisco; KLEIN, Herbert. Evolução da Sociedade e Economia escravista de São Paulo, de 1750 a 1850. São Paulo: EDUSP, 2005.
} 
atingindo grandes índices entre africanos (4.340) e crioulos (748) nos últimos anos, parecendo demonstrar que as charqueadas sempre mantiveram-se fortemente vinculadas primeiro ao tráfico atlântico (até a sua abolição em 1850) e depois ao tráfico interno de escravos (visto o alto índice de homens adultos nos últimos decênios). Portanto, torna-se ainda mais evidente que o declínio da escravidão foi um dos grandes responsáveis pelas crises sofridas pelas charqueadas pelotenses ${ }^{57}$.

TABELA 3

AFRICANIDADE E SEXO NOS PLANTÉIS DOS CHARQUEADORES (1831-1885)

\begin{tabular}{|c|c|c|c|c|c|c|c|c|}
\hline ANOS & \multicolumn{2}{|c|}{$1831-1850$} & \multicolumn{2}{|c|}{ 1851-1865 } & \multicolumn{2}{|c|}{ 1866-1885 } & \multicolumn{2}{|c|}{ Total } \\
\hline \multirow{2}{*}{ AFRICANOS } & \multicolumn{2}{|c|}{314} & \multicolumn{2}{|c|}{422} & \multicolumn{2}{|c|}{222} & \multicolumn{2}{|c|}{958} \\
\hline & $\begin{array}{c}\mathrm{H} \\
270 \\
86 \%\end{array}$ & $\begin{array}{c}\mathrm{M} \\
42 \\
14 \%\end{array}$ & $\begin{array}{c}\mathrm{H} \\
386 \\
91,5 \%\end{array}$ & $\begin{array}{c}M \\
36 \\
8,5 \%\end{array}$ & $\begin{array}{c}\mathrm{H} \\
217 \\
97,7 \%\end{array}$ & $\begin{array}{l}\text { M } 5 \\
2,3 \%\end{array}$ & $\begin{array}{c}\mathrm{H} \\
873 \\
91,1 \%\end{array}$ & $\begin{array}{c}\text { M } 83 \\
8,9 \%\end{array}$ \\
\hline \multirow{2}{*}{ CRIOULOS } & \multicolumn{2}{|c|}{149} & \multicolumn{2}{|c|}{$256^{*}$} & \multicolumn{2}{|c|}{263} & \multicolumn{2}{|c|}{668} \\
\hline & $\begin{array}{c}\mathrm{H} \\
99 \\
66,4 \%\end{array}$ & $\begin{array}{c}M \\
50 \\
33,6 \%\end{array}$ & $\begin{array}{c}\mathrm{H} \\
171 \\
66,8 \%\end{array}$ & $\begin{array}{c}\mathrm{M} \\
84 \\
33,2 \%\end{array}$ & $\begin{array}{c}\mathrm{H} \\
232 \\
88,2 \%\end{array}$ & $\begin{array}{l}\text { M } 31 \\
11,8 \%\end{array}$ & $\begin{array}{c}\mathrm{H} \\
502 \\
75,1 \%\end{array}$ & $\begin{array}{c}\mathrm{M} \\
165 \\
24,9 \%\end{array}$ \\
\hline AFRICANIDADE & \multicolumn{2}{|c|}{$67,8 \%$} & \multicolumn{2}{|c|}{$62,2 \%$} & \multicolumn{2}{|c|}{$45,7 \%$} & \multicolumn{2}{|c|}{$58,9 \%$} \\
\hline $\begin{array}{c}\text { NÃO } \\
\text { IDENTIFICADOS }\end{array}$ & \multicolumn{2}{|c|}{$554(54,5 \%)$} & \multicolumn{2}{|c|}{$344(33,6 \%)$} & \multicolumn{2}{|c|}{$209(30 \%)$} & \multicolumn{2}{|c|}{$1.107(40 \%)$} \\
\hline TOTAIS & \multicolumn{2}{|c|}{1.016} & \multicolumn{2}{|c|}{1.022} & \multicolumn{2}{|c|}{694} & \multicolumn{2}{|c|}{2.732} \\
\hline
\end{tabular}

Fonte: Inventários post-mortem dos cartórios de Pelotas (1831-1885) (APERS)

* Um cativo não teve o sexo identificado

Somando essas informações às da Tabela 4, percebe-se que o grande número de africanos idosos entre 1831 e 1850 confirmam o tráfico para o período de montagem das charqueadas (1790-1820). A grande permanência de idosos africanos nos anos 1870, também evidencia que o comércio ilegal de escravos manteve-se forte após a Lei de 1831, como já mencionei. A média de escravos acima dos 50 anos nos maiores plantéis do agro fluminense (de 1810 a 1830) ficava em torno de $15 \%^{58}$,

${ }^{57}$ Como vários autores já haviam indicado, mas que aqui reforço com outros dados o peso deste processo. Ver: CORSETTI, Estudo da charqueada escravista...; GUTIERREZ, Negros, charqueadas \& olarias...; ASSUMPÇÃO, Pelotas: escravidão...; PESSI, O impacto do fim do tráfico...; PESSI, "A família escrava em Pelotas...".

${ }^{58}$ FLORENTINO, Manolo \& MACHADO, Cacilda. "Famílias e mercado: tipologias parentais de acordo ao grau de afastamento do mercado de cativos (século XIX)". Afro-Ásia, n. 24, 2000, p. 56. Para uma 
enquanto em Pelotas, no período (1831-50), era de $10,5 \% 59$. Tendo em vista a permanência da alta razão de sexo entre os crioulos adultos no último período, percebe-se novamente como os charqueadores conseguiram manter plantéis produtivos, mesmo numa época de crise de mão de obra e envelhecimento dos cativos.

A Tabela 4 demonstra que a taxa de africanidade entre os adultos despencou do primeiro e o terceiro período, na mesma medida em que o percentual de homens crioulos aumentou. Entre os idosos, o aumento do percentual de crioulos e de africanos merece destaque e a pequena presença de escravas nesse grupo revela o forte vínculo das charqueadas com o mercado de escravos. Portanto, os plantéis dos charqueadores foram marcados por um notável desequilíbrio entre os sexos. Isso também se refletia no número de crianças com 7 anos ou menos (Tabela 2). No primeiro período tem-se $4,4 \%$ de crianças nesse grupo, índice que foi de $4,1 \%$ e $2,8 \%$ nos períodos posteriores. Somando as categorias crianças A e B tem-se, respetivamente, 9,1\%, 6,1\% e 6,9\%. Tratava-se de um baixo índice que pode ser explicado pelo pequeno número de escravas nas senzalas dos charqueadores. Analisando dados referentes às plantations de café e açúcar no oitocentos, Florentino e Machado verificaram que unidades com plena inserção no mercado de escravos apresentaram índices entre $15 \%$ e $25 \%$ de crianças ${ }^{60}$, o que demonstra que os charqueadores eram ainda mais dependentes do tráfico, pois a maior parte deles possuía um plantel com baixa reprodução natural.

análise mais aprofundada ver FLORENTINO, Manolo \& GOÉS, José R. A paz nas senzalas: famílias escravas e tráfico atlântico: Rio de Janeiro (c.1790 - c.1850). Rio de Janeiro: Civilização Brasileira, 1997.

${ }^{59}$ No já citado Censo de Pelotas de 1833, verifica-se que este mesmo percentual no município era de $7,6 \%$.

${ }^{60}$ FLORENTINO \& MACHADO, "Famílias e mercado...", p. 53. 
TABELA 4

AFRICANIDADE E SEXO ENTRE ESCRAVOS ADULTOS E IDOSOS (1831-1885)

\begin{tabular}{|c|c|c|c|c|c|}
\hline \multicolumn{2}{|c|}{ SEXO } & $1831-1850$ & 1851-1865 & 1866-1885 & TOTAL \\
\hline \multirow{2}{*}{$\begin{array}{c}\text { AFRICANOS } \\
\text { ADULTOS } \\
\text { DE 15 A } 40 \\
\text { ANOS } \\
\end{array}$} & $\mathbf{M}$ & $157(82,2 \%)$ & $229(94,2 \%)$ & $18(94,7 \%)$ & 404 \\
\hline & $\mathbf{F}$ & $33(17,2 \%)$ & $14(5,8 \%)$ & $1(5,3 \%)$ & 48 \\
\hline \multicolumn{2}{|l|}{ SUBTOTAL } & $191^{*}$ & 243 & 19 & $453^{*}$ \\
\hline \multirow{2}{*}{$\begin{array}{c}\text { CRIOULOS } \\
\text { ADULTOS } \\
\text { DE } 15 \text { A } 40 \\
\text { ANOS } \\
\end{array}$} & $\mathbf{M}$ & $44(67,7 \%)$ & $94(81,1 \%)$ & $150(90,3 \%)$ & 288 \\
\hline & $\mathbf{F}$ & $21(32,3 \%)$ & $22(18,9 \%)$ & $16(9,7 \%)$ & 59 \\
\hline \multicolumn{2}{|l|}{ SUBTOTAL } & 65 & 116 & 166 & 347 \\
\hline \multicolumn{2}{|c|}{$\begin{array}{c}\text { AFRICANIDADE } \\
\text { (ADULTOS) }\end{array}$} & $74,6 \%$ & $67,7 \%$ & $10,3 \%$ & $56,6 \%$ \\
\hline \multicolumn{2}{|l|}{ TOTAL } & 256 & 359 & 185 & 800 \\
\hline \multirow{2}{*}{$\begin{array}{l}\text { AFRICANOS } \\
\text { IDOSOS }\end{array}$} & $\mathbf{M}$ & $95(92,2 \%)$ & $130(92,2 \%)$ & $196(98 \%)$ & 421 \\
\hline & $\mathbf{F}$ & $9(7,8 \%)$ & $11(7,8 \%)$ & $4(2 \%)$ & 24 \\
\hline \multicolumn{2}{|l|}{ SUBTOTAL } & 104 & 141 & 200 & 445 \\
\hline \multirow{2}{*}{$\begin{array}{l}\text { CRIOULOS } \\
\text { IDOSOS }\end{array}$} & $\mathbf{M}$ & $21(80,7 \%)$ & $26(83,8 \%)$ & $61(93,8 \%)$ & 108 \\
\hline & $\mathbf{F}$ & $5(19,3 \%)$ & $5(16,2 \%)$ & $4(6,2 \%)$ & 14 \\
\hline \multicolumn{2}{|l|}{ SUBTOTAL } & 26 & 31 & 65 & 122 \\
\hline \multicolumn{2}{|c|}{$\begin{array}{l}\text { AFRICANIDADE } \\
\text { (IDOSOS) }\end{array}$} & $80 \%$ & $82,9 \%$ & $75,4 \%$ & $78,5 \%$ \\
\hline \multicolumn{2}{|l|}{ TOTAL } & 130 & 172 & 265 & 567 \\
\hline
\end{tabular}

Fonte: Inventários post-mortem dos cartórios de Pelotas (1831-1885) (APERS)

Com relação à razão de sexo, enquanto nos plantéis analisados por Florentino $e$ Machado os homens ficavam na casa dos 53\% (Engenho Novo da Pavuna - 1852) e $59 \%$ (Fazenda Resgate - 1872), em Pelotas a média era de $82 \%$ no período. Portanto, se o plantel da Fazenda Resgate, em Bananal, durante a década de 1860, conseguia reproduzir-se de forma natural ${ }^{61}$, o mesmo não pode ser dito para as charqueadas. Nesse sentido, esses estabelecimentos constituíam-se em unidades fabris com semelhanças e diferenças se comparados às plantations açucareiras $e$ cafeicultoras. Se a taxa de africanidade delas era bastante parecida, a menor presença de mulheres aumentava a dependência do charqueador para com o mercado de escravos, pois elas apresentavam uma baixa reprodução natural e certamente um menor índice de famílias conjugais, o que não significa que os cativos não estivessem imersos em malhas parentais na senzala e mantivessem relações fora dela. Num contexto de fechamento do tráfico atlântico pós-1850, tratava-se de um enorme

${ }^{61}$ FLORENTINO \& MACHADO, "Famílias e mercado...", p. 57. 
problema a ser revolvido por estes empresários. Assim, a diminuição do número de charqueadas de 38 (em 1880) para 11 (em 1900) demonstra que, apesar de não constituir-se no único fator, a abolição da escravidão foi fatal para as charqueadas de Pelotas, sendo que os charqueadores não foram capazes de encontrar saídas satisfatórias para superar as muitas crises que afetaram o setor entre as décadas de 1860 e $1880^{62}$.

\section{$\operatorname{son}$}

\section{RESUMO}

$\mathrm{O}$ charque constituiu-se em importante produto que compunha a dieta dos escravos das plantations do sudeste e do nordeste do Brasil oitocentista. Nesse contexto, a cidade de Pelotas, no Rio Grande do Sul, foi a principal produtora de carne-seca do Império e desde os seus primórdios dependeu fortemente do uso da mão de obra escrava para o seu desenvolvimento econômico. Por conta disso, os Barões do charque foram os maiores proprietários de cativos do Brasil meridional $e$ os mesmos constituíram-se na elite econômica da província sulina. O presente artigo analisa a presença dos escravos nas charqueadas pelotenses, seu perfil social e etário, os serviços nos quais os mesmos estavam empregados, assim como os processos de produção de charque e dos couros.

Palavras Chave: Escravidão; Brasil; Charque.

\begin{abstract}
The charque (jerky beef) was an important product that made up the diet of the plantations slaves in the south-eastern and north-eastern $19^{\text {th }}$ century Brazil. In that context, the city of Pelotas, Rio Grande do Sul Province, was the leading producer of dried meat in Imperial Brazil $e$ and from its beginnings strongly depended on the use of slave labour for their economic development. Therefore, the jerky beef Barons were the largest slave owners in southern Brazil and became the economic elite of the southern province. This paper analyses the presence of slaves in the charqueadas (jerky beef's manufactories) in that area, their social and age profiles, the services on which they were employed, as well as the jerky beef and leather production processes.
\end{abstract}

Keywords: Slavery; Brazil; Jerky Beef.

Artigo recebido em 26 jan. 2016.

Aprovado em 06 ago. 2016.

${ }^{62}$ VARGAS, Pelas margens do Atlântico... 